\section{Long-term Financing: Exploring the Recent Advances in the Brazilian Bond Market}

\author{
Financiamento de Longo Prazo: Explorando o Avanço Recente do \\ Mercado de Debêntures Brasileiro
}

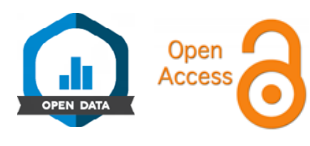

Lucas Boareto da Aparecida' ${ }^{\circ}$

Sergio Giovanetti Lazzarini' 10

Adriana Bruscato Bortoluzzo*1 0

\section{ABSTRACT}

Context: in Brazil, there was an expansion of private funding via bond issuances, especially since 2017. Before that period, the sources of longterm financing were concentrated on public funding. Objective: this study aims to explore the main factors that could have positively affect Brazilian bond market and if it would be possible to improve project financing through this debt instruments. Methods: using mixed methods with econometric tests and qualitative interview analysis, this study assesses which were the factors that supported this growth and if there is any difference across industries. Results: we found that a change in the market trend has indeed happened around 2017, and it was more pronounced in specific industries such as electricity. Interviewees suggested that increases in demand (possibly triggered by the reduction of public sources of funding and the fall in local interest rates) could be the main factors that supported this change in trend. Conclusions: therefore, this study reinforces the importance of local market conditions and government policies affecting the relative attractiveness of private versus public sources of corporate investment.

Keywords: long-term financing; bond market; state participation; private sector participation.

\section{RESUMO}

Contexto: houve no Brasil uma expansão de captaçóes privadas via debêntures, especialmente a partir de 2017. Antes disso, as fontes de financiamento de longo prazo se concentravam na captaçáo via recursos estatais. Objetivo: o estudo examina as possíveis razôes dessa expansão e como ela poderia sugerir uma nova tendência de financiar uma maior parcela de projetos de infraestrutura com capital privado. Métodos: por meio de uma abordagem de pesquisa mista, envolvendo testes econométricos de quebra estrutural em séries temporais e análises qualitativas de entrevistas com profissionais do mercado financeiro. Resultados: foi confirmado que houve uma mudança na tendência de emissão de debêntures a partir de 2017, mais pronunciada em alguns setores específicos, como o elétrico. Utilizando entrevistas, sugerimos que os fatores determinantes estáo relacionados ao crescimento da demanda por esses títulos de dívida e à redução nas taxas de juros no Brasil. Conclusôes: assim, o estudo reforça a ideia da importância das condições do mercado local e das políticas governamentais e seu efeito na atratividade relativa entre o capital privado e o capital público no financiamento corporativo.

Palavras-chave: financiamento de longo prazo; infraestrutura; debêntures; financiamento público.

\footnotetext{
* Corresponding Author.

1. Instituto de Ensino e Pesquisa (INSPER), São Paulo, SP, Brazil.
}

Cite as: Aparecida, L. B. da., Lazzarini, S. G., \& Bortoluzzo, A. B. (2022). Long-term financing: Exploring the recent advances in the Brazilian bond market. Revista de Administração Contemporânea, 26(2), e210076. https://doi.org/10.1590/1982-7849rac2022210076.en
JEL Code: $E$.

Editors-in-chief: Wesley Mendes-da-Silva (Fundação Getulio Vargas, EAESP, Brazil) Marcelo de Souza Bispo (Universidade Federal da Paraíba, PPGA, Brazil) Reviewers: Michele Nascimento Jucá (Universidade Presbiteriana Mackenzie, CCSA, Brazil) Hsia Hua Sheng (Fundação Getulio Vargas, EAESP, Brazil) (ct) Peer Review Report: The Peer Review Report is available at this external URL.

\begin{tabular}{|c|c|c|c|c|c|c|c|c|c|}
\hline & 1 & 2 & 3 & 4 & 5 & 6 & 7 & 8 & 9 \\
\hline $1^{\text {st }}$ round & (x) & $\stackrel{8}{6}$ & (x) & $\stackrel{8}{2}$ & & & & & \\
\hline $2^{\text {nd }}$ round & $\stackrel{\varphi}{=}$ & (x) & & & & & & & \\
\hline
\end{tabular}




\section{INTRODUCTION}

There is a long debate on how to finance infrastructure projects. The literature indicates that such projects involve long-term assets and that they require large amounts of funds (Ehlers, 2014). Developed countries have several ways to fund infrastructure projects, through funding structures from the private sector, or from government sources or state guarantees, given the lower cost of state capital (Shaoul, 2005; Aghion, 1999). However, regions with credit restrictions, such as emerging economies, have a series of limitations on the use of such mechanisms. Credibility risks and low visibility of the return on investments end up inhibiting the attraction of private capital, thus limiting infrastructure projects that could generate important productivity gains (Ehlers, 2014).

Given these difficulties, a possibility that often arises is to use governmental funding to leverage such investments. State-owned banks are often used by governments to fund projects with positive externalities, that is, with social, economic, and environmental gains generated by investments (Aghion, 1999; Bruck, 1998). However, institutional weakness in emerging economies also generates costs for state action. For example, stateowned banks can generate misallocation of public resources in less productive projects or for companies with no apparent credit restrictions, which could be financed by the private sector (Lazzarini, Musacchio, Bandeira-de-Mello, \& Marcon, 2015).

In this sense, this paper seeks to shed a light on this debate by assessing the recent Brazilian experience of infrastructure funding in Brazil. Traditionally, the Economic and Social Development Bank (BNDES), as a public agent, played a relevant role in supporting infrastructure projects (Bragança, Pessoa, \& Souza, 2015; Lazzarini et al., 2015; Lazzarini, Lima, \& Makhoul, 2017; Musacchio, Lazzarini, Makhoul, \& Simmons, 2017; Wajnberg, 2014). However, from 2017 onward, there was a clear expansion of the debenture market. Accord-ing to data from the Brazilian Association of Financial and Capital Market Entities (Associação Brasileira das Entidades dos Mercados Financeiro e de Capitais - Anbima), more than half of the debentures issuance carried out between 1995 and 2019 were made from 2017 on. In fact, Brazil already had a debenture market with a size that corresponded to $18 \%$ of the country's gross domestic product (GDP) in the first decades of the 20th century (Musacchio, 2009), higher than the $9 \%$ level reached in 2019, according to data from Anbima and the Brazilian Institute of Geography and Statistics (Instituto Brasileiro de Geografia e Estatística - IBGE). According to Musacchio (2009), in this period, the country's legislation had several instruments to support creditors, which increased investors' security to allocate their resources in debentures.

Specifically, the objective of this paper is to analyze this recent expansion of debentures in Brazil and list its possible determining factors. Based on this initial question, the hypothesis that there was a structural change in the Brazilian debenture market was tested by using a statistical model of time series. Then, it was assessed, through qualitative methodology (interviews), what the possible factors that drove this change may have been. Therefore, the study adopted mixed research, involving quantitative and qualitative data. This method is justified by the complexity of the phenomenon studied and the importance of contextual factors, such as changes in regulatory conditions or, more broadly, institutional factors (Sale, Lohfeld, \& Brazil, 2002).

The quantitative stage seeks to determine when the change in the behavior of the debenture market in Brazil occurred, through the econometric method of structural breaks. This type of test is often used in models based on time series, showing trend changes and the existence of abnormal effects in these series (Ferreira, Menezes, \& Oliveira, 2013). In the case of this study, a database made available by Anbima was used, containing information on debentures issuance of 727 companies between 1989 and 2019. The qualitative stage sought to give empirical support to the quantitative results through an exploratory analysis of interviews with treasury professionals from frequent debentures issuers. Interviews are recurrently used to seek depth regarding the phenomenon explored, in addition to being a way of selecting the source of the information being pursued (Stokes \& Bergin, 2006).

The quantitative results of the study suggest that, in fact, there was a change in the trend in debenture issuance in the Brazilian market from 2017 onward, both for the market as a whole and for the sectors assessed. Furthermore, it was possible to observe that some of the sectors included in this study had a statistically superior performance than others - notably, the electricity sector, with an average annual growth of 55\% in issue of debentures as of 2011 .

A qualitative analysis complements previous results by showing possible determinants of this evolution. According to participants, the drop in the Brazilian federal funds rate (Selic), associated with a reduction in subsidies in the rates practiced by BNDES, could have boosted the debentures issuance by Brazilian companies. In addition, there was also an increase in demand for these securities as a result of the drop in the interest rates in Brazil and the growing experience of local actors in using private sources of credit. 
Thus, in the academic sphere, the results reinforce the importance of factors related to the economic and institutional environment affecting the transaction costs of economic agents and allowing arrangements in the private context (Musacchio et al., 2017; Paula \& Faria, 2012). However, the study also indicates that factors at the country level are heterogeneous from effects that occur on the sector level. Therefore, there is room for advances in approaches that integrate institutional factors with dynamics that occur in sectors with particular financing demands. In the applied context, the study suggests that the Brazilian capital market could be able to apply private credit sources, if public policies sought to reduce systemic capital costs and foster local learning in new forms of financing. With this, state entities would have more space to focus their efforts on companies with credit restrictions, thus allowing the private sector to cater to the needs of companies without funding limitations.

\section{LITERATURE: INFRASTRUCTURE FUNDING AND THE ROLE OF PUBLIC AND PRIVATE SOURCES}

Infrastructure investments have aspects that make their funding a tough issue to resolve. Problems related to long-term viability and uncertainties regarding return on investment jeopardize their analysis by private partners (Ehlers, 2014). Furthermore, in emerging economies, political and legal risks would be important aspects in the evaluation of these investments (Ehlers, 2014). In addition to this view, Alles (2001) explores the limitations that private banks have in lending resources in the long term. Financial institutions are governed by regulations created to guarantee liquidity to depositors, thus avoiding excessive risk exposures, which occurs in late-maturing projects (Alles, 2001).

On the other hand, developed economies, such as the United Kingdom, created programs focused on the private sector to fund the modernization of the country's infrastructure, including roads, prisons, hospitals, and schools in the 1990s. An argument in favor of this initiative, called the Private Finance Initiative (PFI), was its generation of value compared to the resources spent on projects. Another important factor considered at the time was the transfer of financial risks to the private sector, which would be apparently positive for taxpayers (Shaoul, 2005).

However, studies on state intervention in the financial system suggest that without government participation, lack of trust between creditors and investors would impact credit market development (Gerschenkron, 1962). As ordinary banks have regulatory limitations on risk exposure, innovative projects could be sidelined because of such restrictions (Alles, 2001; Bruck, 1998).

One way of enabling government funding participation in project support is the use of development banks (Aghion, 1999). According to the author, these institutions invest more in the expertise needed to support long-term projects than private banks. Specifically in developing economies, Amsden (1992) points out that development banks not only were important in supporting long-term projects, but also were good instruments for identifying and monitoring investment projects. However, according to Aghion (1999), there is a general perception that development banks in emerging countries would often fail to replicate successful models. High tardiness rates, poor cost-benefit assessments, and cases of corruption associated with mismanagement contributed to this negative image (Aghion, 1999).

Transporting the reasoning to the Brazilian context, several authors indicate the difficulty of financing long-term projects in Brazil (Armijo \& Rhodes, 2017; Bragança et al., 2015; Lazzarini et al., 2015; Machado, Martini, \& Gama, 2017; Torres \& Costa, 2012; Wajnberg, 2014). One of the causes mentioned is the lack of long-term private capital (Alles, 2001; Ehlers, 2014; Maksimovic \& Demirgückunt, 2002). However, Musacchio (2009) suggests that the debt capital market was once the main source of capital for projects in Brazil. The author points out that the national bond market (also known as debentures) played an important role in the financing of Brazilian companies after 1880 , which can be demonstrated by the expressive growth in the volume of issuances seen in that period, when this market was equivalent to $60 \%$ of the size of the Rio de Janeiro stock exchange (Musacchio, 2009).

An important point of this discussion is to understand what the economic and regulatory conditions that supported this market might have been. Porta, Lopezde-Silanes, Shleifer and Vishny (2014) defined some important regulatory factors to establish a solid financial system. Among these conditions, the right of creditors to recover guarantees received in case of default, priority in judicial repossession processes, and the right to appoint executives in debtor companies stand out (Porta, Lopez-deSilanes, Shleifer, \& Vishny, 2014). According to Musacchio (2009), between 1850 and 1945, the Brazilian legislation had relatively strong instruments to protect creditors, such as the priority of debenture holders in relation to other creditors of a company.

However, over the following decades, BNDES gained relevance in funding large projects, focusing its efforts on supporting state and private companies (Najberg, 1989). On the other hand, Lazzarini, Musacchio, Bandeira-deMello and Marcon (2015) suggest that it was not possible 
to observe a consistent positive impact on the volume of investments and performance of companies that raised funds with the BNDES in the period evaluated. In this study, the authors accessed data from 286 companies and used two competing views, industrial and party policies, to support the tested hypotheses. According to Bruck (1998), from the perspective of industrial policy, development banks may demand certain performance standards when lending resources, with the objective of extracting the best results from a project.

Meanwhile, according to Lazzarini et al. (2015) and Musacchio and Lazzarini (2015), following the vision of party policy, development banks can become state instruments to support companies in difficulty or even politically benefit companies with a good relationship with the government. This fact may imply a greater capacity of companies that have ties to the government to acquire funds from these state-owned institutions (Dinç, 2005).

The results suggest that companies that would have the capacity to access other sources of long-term financing chose to take subsidized resources from BNDES, which would be evidence of the substitution of private sources of financing with public ones (Lazzarini et al., 2015). Musacchio et al. (2017) explore this phenomenon of crowding out of private intermediaries by development banks. According to the authors, these institutions would be reducing the attractiveness of the private sector in financing projects by supporting investments with subsidized rates. From another perspective, Ferraz and Coutinho (2019) argue that BNDES has followed development objectives and that most of the resources made available by the bank were directed to projects seeking to develop industrial sectors and create jobs.

It is worth noting that, in emerging economies, the domestic capital market has been gaining space as a source of financing for corporations. Abraham, Cortina and Schmukler (2021) show that the Asian domestic bond market grew more sharply than the international market for companies in this region between 1990 and 2016, with an increase of $125 \%$ in the number of issuers per year in the comparison between the periods 1990-1998 and 20082016, which suggests the existence of alternatives to local bank financing.

In general, it is clear that, regardless of the source of financing, a developed financial system tends to support economic growth in a sustained way. Private sector involvement can improve execution and fundraising for infrastructure projects. The role of the public sector, in this case, would be to provide the necessary conditions for this involvement of the private sector to take place in the best possible way. As infrastructure investments usually have a long maturity period, the risk of political issues negatively impacting these projects increases. Lenders and investors would find it easier to provide long-term resources if they could rely on the legal and political procedures of the regions where the investments are made (Ehlers, 2014).

\section{EMPIRICAL CONTEXT AND METHODS}

\section{Infrastructure funding in Brazil}

Historically, Brazil has underinvested in infrastructure projects (Lazzarini et al., 2017). Although BNDES expenditure for this purpose went from approximately $\mathrm{R} \$ 15$ billion, in 2005 , to roughly $\mathrm{R} \$ 70$ billion, in 2014, the investment rate in relation to the Brazilian GDP is one of the lowest in the world, with an average of ten percentage points below the world average and four percentage points below Latin American countries and the Caribbean, according to estimates by the Brazilian Institute of Economics of the Getúlio Vargas Foundation (Instituto Brasileiro de Economia da Fundação Getúlio Vargas — IBRE/FGV).

In fact, the Brazilian state has played a relevant role in funding projects through BNDES. In the first decade of its operations, $69 \%$ of the initiatives funded by the bank were associated with infrastructure projects, which recently correspond to $36 \%$. However, in the decades that followed, the bank's focus changed and BNDES started to finance more projects linked to the national industrial sector. More recently, as of 2011, sectors linked to commerce and services gained space in the bank's financing portfolio (approximately 24\%), mainly due to projects such as the PSI (Programa de Sustentação do Investimento) and the BNDES Card, according to data from the annual performance report of the bank in Barboza, Furtado and Humberto (2018).

Another repeatedly discussed factor is the size of BNDES in relation to the Brazilian economy. Barboza et al. (2018) present this evolution by comparing the size of the bank with the GDP and gross fixed capital formation (formação bruta de capital fixo - FBFC) of Brazil. Until 1999, the magnitude of BNDES in relation to GDP was below $1.0 \%$ most of the time, a value that exceeded $2.0 \%$ from the 2000s onward.

Another form of state participation in financing the economy is the portfolio of debenture operations owned by BNDES. Historically, BNDESPar (BNDES investment entity) has been an active participant in the debenture market. The position of such security in the bank's portfolio, which has already exceeded $\mathrm{R} \$ 20$ billion, lost relevance in relation to the market as a whole as of 2005 , going from a $20 \%$ market share to $2 \%$ at current levels. 
However, from 2017 onward, it is possible to observe a significant advance in the issuance of private debt securities (debentures) in Brazil. In 2011, the socalled incentive debentures were created, with income tax exemption for individuals, in accordance with Law 12,431 (Bragança et al., 2015; Wajnberg, 2014). According to data from Anbima, between 2013 and 2018, on average, companies issued 18 infrastructure debenture transactions, a number that rose to 42 transactions in 2017 and 65 in 2018. However, it was around 2017 that these mechanisms had a substantial boost. Since 1995, Brazilian companies have issued more than $\mathrm{R} \$ 700$ billion in debentures, with more than half of this volume occurring only from 2017 onward.
The debentures issued in the last 20 years are concentrated in ten sectors, which were responsible for more than $90 \%$ of these operations. Excluding the financial sector from this analysis, the segments of electricity (14\%), transport and logistics (7\%), and retail trade $(5 \%)$ had a relevant participation in these emissions, accounting for almost $26 \%$ of operations in this period.

As shown in Figure 1, as of 2016, most of the sectors assessed had an increase in their emissions compared to 2011. Among these segments, the electricity sector stands out, with an average growth exceeding $55 \%$ a year.

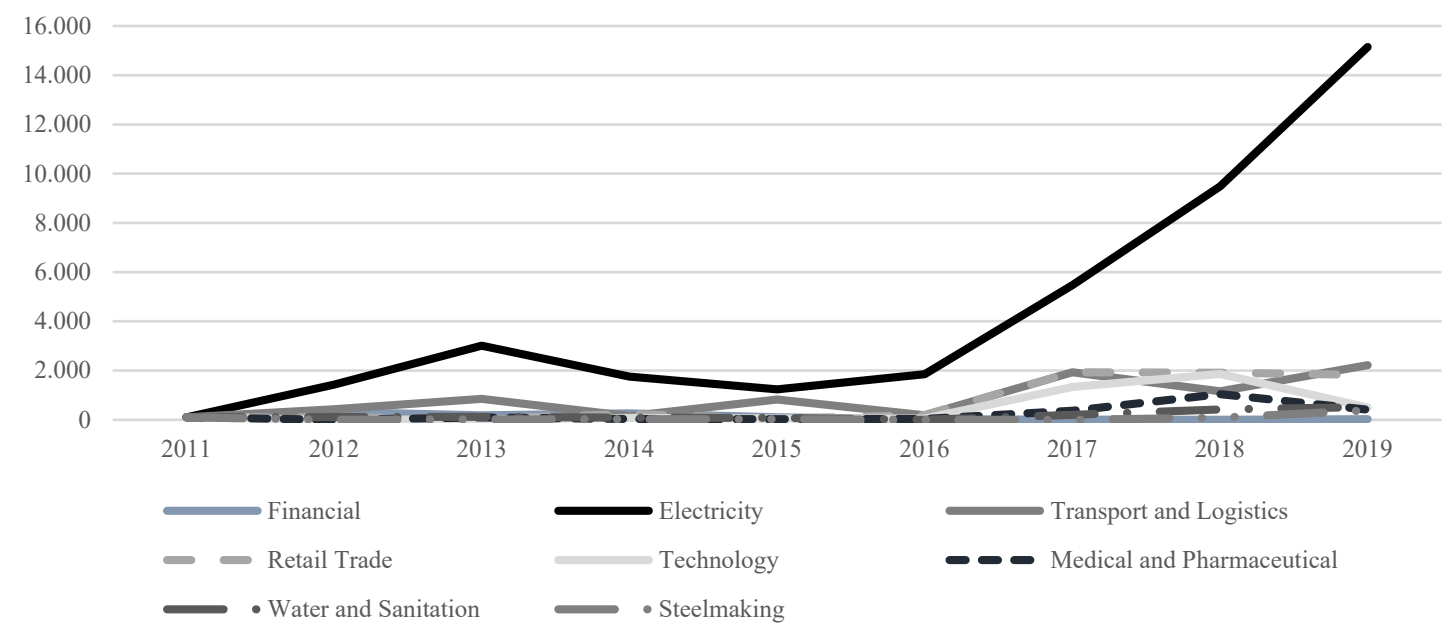

Figure 1. Evolution of debenture issue volume by sector - Base $100=2011$.

Source: Elaborated by the authors based on data from Anbima (https://www.anbima.com.br/pt br/pagina-inicial.htm retrieved on December 15, 2019).

Specifically for infrastructure debentures, this instrument has been gaining relevance in recent years, reaching the same level of BNDES infrastructure expenditure in September 2019, around R $\$ 17.4$ billion in the first nine months of that year. In addition, according to the Ministry of Economy (Ministério da Economia, 2021), 56.8\% of investments in infrastructure in the electricity sector were financed by debentures, a figure that reached $44.2 \%$ in the transport and logistics sector and $60.6 \%$ in the water and sanitation sector, according to the Newsletter of Incentive
Debentures - January 2020, which used data from Anbima and ministerial orders to compile data on participation in infrastructure projects.

With regard to the demand for these debt instruments, data from Anbima show that from 2018 onward both the shareholders' equity and the number of shareholders of these funds have grown sharply (above four times). Therefore, it can be inferred that the growth in the supply of this type of security, as shown above, was also supported by an evolution in its demand. 


\section{METHODOLOGY}

The behavior seen in the debentures market in Brazil is recent and still very poorly explored in the academic sphere. Furthermore, the phenomenon involves a complex set of economic and institutional issues, which implies a broader assessment of the factors that influence it. Thus, we opted for a mixed method combining quantitative and qualitative steps.

Authors within the social science spectrum suggest that quantitative and qualitative methodologies could be used in a complementary way and that these strategies would not be mutually exclusive (Webb, Campbell, Schwartz, \& Sechrest, 1966). One of the most used arguments in favor of mixed methods is the possibility of triangulation, that is, the use of different reference sources to approach the same phenomenon (Jick, 1979). Campbell and Fiske (1959) developed the idea that the use of mixed methods would be important to validate the results obtained and that the convergence of these methodologies would be a source of robustness. Furthermore, in certain areas of study, mixed methodology is seen as an interesting way to explore complex phenomena that require information from different sources and perspectives (Clarke \& Yaros, 1988).

That said, as the study addressed a phenomenon that has been vaguely investigated, exploring the context in which it occurs and its motivations and particularities requires the use of a qualitative methodology. In this case, this study was exploratory in nature, which is appropriate when the objective is to develop relevant propositions, which can be analyzed later. In addition, the debentures issuances and infrastructure financing have a vast database, which enabled a quantitative analysis of the behavior of these variables. Thus, this study evaluated the recent evolution of the debenture market through public data on these operations, in addition to exploring what would be the factors that contribute to this behavior and, also, if there are specific sectorial aspects that affect it.

\section{Quantitative stage}

The quantitative stage seeks to test the hypothesis that there has been a structural break in the evolution of debenture issue in Brazil recently. For this purpose, data from Anbima were collected, covering operations between 2011 and 2019. During this period, 1,475 operations are included in Anbima's database, totaling a volume of R $\$ 576$ billion.

In this test, the econometric methodology of structural breaks in time series was used. As presented in Zarei, Ariff, Hook and Nassir (2015), Ferreira, Menezes and Oliveira (2013), Perron (2006) and Hansen (2001), this type of methodology makes it possible to determine when a certain trend has changed over time. The method used in this study seeks to define structural breaks at unknown dates, as demonstrated in Jouini and Boutahar (2005), Andrews (1993) and Zivot and Andrews (1992), by performing multiple Wald tests.

The Wald test is determined by Equation (1):

$W_{T}=\frac{\left(\hat{\theta}-\theta_{0}\right)^{2}}{\left[I_{n}(\hat{\theta})\right]^{-1}}=I_{n}(\hat{\theta})\left[\hat{\theta}-\theta_{0}\right]^{2}$

where $\hat{\theta}$ is the maximum likelihood estimator (MLE); $\theta_{0}$ is the value assumed by $\hat{\theta}$ under the null hypothesis $\left(\mathrm{H}_{0}\right)$; and $I_{n}(\hat{\theta})$ is Fisher's expected information. The test follows the distribution $\chi^{2}$ under the null hypothesis $\left(\mathrm{H}_{0}\right)$.

To determine a structural break, the Wald test checks how extreme the evaluated sample is, that is, the greater the distance $\hat{\theta}-\theta_{0}$, the greater the probability of rejecting the null hypothesis $\left(\mathrm{H}_{0}\right)$ that at the point tested there is no structural break.

In the case of this study, as its objective was to verify whether there is a structural break within a time series, one way to operationalize this procedure was to perform a Wald test for each month of the tested time series. This set of multiple Wald tests is known as the ultimate Wald test and, assuming $q$ as a break date within a range $\left[q_{1}, q_{2}\right]$, for a sample of size $T$, the ultimate Wald test statistic for testing the null hypothesis $\left(\mathrm{H}_{0}\right)$ that there is no structural break in the years tested is given by (2):

$S_{T}=\sup _{q_{1} \leq q \leq q_{2}} S_{T}(q)$

A second step of the quantitative tests was the determination of the intensity of the structural break by sector. For this purpose, information was used from the segments that had a relevant participation in the issue of debentures in the period in question, that is, issue greater than $\mathrm{R} \$ 10$ billion in the period evaluated, namely: finance, electricity, transport and logistics, retail trade, IT and telecommunications, healthcare/pharmaceuticals, sanitation, and steelmaking.

Then, the augmented Dickey-Fuller unit root test (ADF) was performed to assess the stationarity of the series. Then, the effect of the break in the monthly volume of debentures issued was separately estimated using the natural $\log$ of the volume of debentures issued to stabilize the variance of the issue series, including the necessary lags according to the auto-correlation function (funçâo de autocorrelação - FAC) of each series, according to (3): 


$$
\ln \left(y_{i t}\right)=\alpha_{0 i}+\alpha_{1 i} \cdot \ln \left(y_{t-1 i}\right)+\alpha_{2 i} \cdot Q_{t i}+\varepsilon_{i t}
$$

where $\ln \left(y_{i t}\right)$ is the expected percentage change in the monthly volume of debentures in the $\mathrm{i}^{\text {th }}$ sector evaluated, as a function of the month of the break and the percentage change in the monthly volume calculated in the immediately preceding period $Q_{t i}$ is the dummy variable that takes value zero for the months before the structural break and one for the break month and later periods; and $\varepsilon_{i t}$ is the random error.

Next, in order to compare the sectoral effect on the total volume issued by the debenture market after the crash, a panel estimation was used. In this case, as the panel model is dynamic, its estimation was performed by using the two-stage least squares method (2SLS). Thus, the volume calculated in $t-2$ and the variation between the volumes in $t-1$ and $t-2$ were used as instruments, as shown in (4):

$\ln \left(y_{i t}\right)=\beta_{0}+\beta_{i} \cdot \ln \left(y_{i t-1}\right)+\sum_{i=1}^{j-1} \delta_{i} \cdot Q_{t} \cdot S_{i}+\sum_{i=1}^{j-1} \gamma_{i} \cdot S_{i}+\varepsilon_{i t}$

where $\ln \left(y_{i t}\right)$ is the expected percentage variation of the total monthly volume of debentures depending on the sector, the temporal effect, and the month of the break; $\delta i$ is the parameter associated with the interaction between the structural break dummy $(Q)$ and the sector dummies $\left(S_{i}\right)$, which represents the sectoral effect on the percentage change in the total monthly volume of debentures after the structural break, in relation to a sector of reference; $S_{i}$ is a dummy variable that takes value one if the issued volume is from the sector in question; $i$ is the sector indicator; $j$ is the number of sectors evaluated; and $\varepsilon_{i t}$ is the random error.

\section{Qualitative stage}

In order to support the quantitative results of this study, interviews were conducted with participants in the Brazilian financial market, seeking possible explanations for this break in the debenture issuance trend in Brazil. Next, the content analysis method was used in the process of analyzing the data collected in the interviews. It is a specific methodology to analyze written and verbal communication, which will be important in the evaluation of the interviews conducted herein (Elo \& Kyngäs, 2008).

The interview process started by defining the questions, which was followed by the creation of a semistructured script and, finally, the choice of the interviewees. Find below the list of questions that were shown to the participants of this study:
1. How did your company finance major projects until 2017? Government funding (BNDES, for example)? Capital market? Private credit?

1. What are the most attractive sources of financing at the moment in your opinion?

1. Do you think there has been any change in the way your company finances major projects from 2017 onward?

1. What factors have driven this change in your opinion (if there are any)?

1. In your view, is the current trend of a high participation level of the capital market in financing options for large projects sustainable?

1. What structural changes would be important to further boost the national debenture market?

The first question in the questionnaire was asked to verify whether the state was an important source of financing for companies. As explored in Machado et al. (2017), Musacchio et al. (2017), Lazzarini et al. (2015), Musacchio and Lazzarini (2015) and Machado, Grimaldi, Albuquerque and Santos (2014), the high level of state participation in funding corporations is often questioned and, as the authors suggest, in many cases there is no statistical evidence that this support has increased the intention of these companies to invest in large projects.

Regarding the second and third questions, their main objective was to seek evidence on how firms are financing themselves at the moment. An important point of this question is whether there really was a change in the behavior of companies, whether they started to access the capital market when financing long-term projects.

Question 4 served to complement the two previous questions, in addition to confirming what was previously exposed in the contextualization and literary reference sections. As suggested by Castro, Kalatzis and Martins-Filho (2015) and Ehlers (2014), the macroeconomic environment and the structure of the financial system are important factors that impact the decision-making process of companies when investing and how to finance themselves.

Subsequently, Question 5 is associated with the perpetuity of the moment experienced by the debenture market as of 2017. According to what was presented, the debenture market has grown significantly in the last three years, being responsible for a significant portion of project financing in important sectors of the domestic economy (Ministério da Economia, 2021). That said, it was important to verify whether, in the view of the professionals approached, this change in performance could have lasting effects. 
Finally, the last question in the questionnaire sought indications on how the state could create rules that facilitate access to the capital market, both for issuers and investors. This fact was addressed by authors such as Castro et al. (2015), Ehlers (2014), and Beck and Levine (2002), who explored state measures that could give more support to this market.

Next, informants who could present accurate and reliable reports on the subject discussed were sought (Cabral \& Krane, 2018). For this, ten professionals who work in the financial department of debenture issuers were interviewed. We have selected executives with more than 13 years of professional experience on average, four from the electricity sector, four from the retail trade sector, one from the transport and logistics sector, and one from the steelmaking sector.

Preliminary analyses indicated that the chosen sectors had a relevant participation in the volume of debenture issuances, but with different performances. In addition, the selected sectors have different capital needs, which made it possible to examine heterogeneous responses on factors that may have influenced the evolution of the debenture market. The largest number of professionals in the electricity sector and retail trade was due to the broad spectrum of companies that are frequent issuers in comparison with the other segments evaluated.

Finally, all conversations were transcribed and analyzed using the content analysis method. At this stage, following the process used by Elo and Kyngäs (2008), White and Marsh (2006), Hsieh and Shannon (2005) and Stemler (2001), some initial ideas were defined about themes that could emerge from the interviews, using the bibliographic references as a basis, in a deductive process. In this type of approach, we seek to revisit information that has already been analyzed in a different context (Elo \& Kyngäs, 2008). Then, the interviews were analyzed, recognizing the themes previously defined and verifying the frequency with which they appeared and their context.

\section{QUANTITATIVE RESULTS}

The results suggest that the evaluated datasets are stationary based on the ADF unit root test (Table 1). Regarding the structural break test (Table 1), the results were statistically relevant within a $95 \%$ confidence interval, except for the financial sector. The tests suggest that there were changes in the trend of debenture issue throughout 2017 in the market in general, except in the steelmaking industry, which showed a statistically significant change in trend in August 2018.

As the time series were stationary, before estimating the regression model, the existence of a correlation between the volume of debentures issued in the past and the volume in the period evaluated was assessed based on the correlogram (FAC), shown in Table 1. The results suggest that the sectors of electricity, transport and logistics, health insurance, and pharmaceutical manufacturing, as well as the market in general, showed the existence of a serial correlation. Thus, for these cases, the lag must be included in the regressions.

Table 1. ADF test (unit root), structural break test, and FAC (correlogram) of the debenture issue time series.

\begin{tabular}{|c|c|c|c|c|c|}
\hline \multirow{2}{*}{ Sector } & \multicolumn{2}{|c|}{ ADF test } & \multicolumn{2}{|c|}{ Structural break tests } & \multirow{2}{*}{$\begin{array}{c}\text { FAC test } \\
(\text { correlogram })\end{array}$} \\
\hline & No of observations & Statistics of the test & Estimated date & Statistics of the test & \\
\hline Financeiro & 107 & $-10.111^{* * *}$ & February/15 & $8.274^{*}$ & 0.020 \\
\hline Energia Elétrica & 107 & $-5.821^{* * *}$ & September/17 & $47.470^{* * *}$ & $28.970^{* * *}$ \\
\hline Transporte e Logística & 107 & $-8.389^{* * *}$ & June/17 & $31.833^{* * *}$ & $4.301^{* *}$ \\
\hline Comércio Varejista & 107 & $-9.485^{* * *}$ & April/17 & $43.928^{* * *}$ & 0.658 \\
\hline TI e Telecomunicações & 107 & $-9.371^{* * *}$ & February/17 & $15.962^{* * *}$ & 0.881 \\
\hline Ass. Médica/Prod. Farm. & 107 & $-7.762^{* * *}$ & August/17 & $40.682^{* * *}$ & $8.120^{* * *}$ \\
\hline Saneamento & 107 & $-8.701^{* * *}$ & July/17 & $15.381^{* * *}$ & $2.911^{*}$ \\
\hline Metalurgia e Siderurgia & 107 & $-9.017^{* * *}$ & August/18 & $22.856^{* * *}$ & 1.792 \\
\hline Mercado Total & 107 & $-6.431^{* * *}$ & August/17 & $65.746^{* * *}$ & $20.760^{* * *}$ \\
\hline
\end{tabular}

Note. ${ }^{*}$ p-value $<0.10 ;{ }^{* *}$ p-value $<0.05 ;{ }^{* * *}$ p-value $<0.01$. 
By using the previous results, the effects on the percentage change in the volume of debentures issued were estimated (Table 2) as a function of the date of the structural break and the percentage change in the volume of debentures issued in the immediately preceding period. This last parameter was assessed only for the sectors determined in the FAC test. Regarding the effect of the change in trend $\left(\beta_{2 i}\right)$, the results suggest that all sectors tested had an increase in debenture issue after the structural break with a $95 \%$ confidence, except for the financial sector. As for the temporal effect on the variation in the monthly volume of debentures $\left(\beta_{l i}\right)$, it was possible to observe statistically significant results only for the total debenture market.

From the change in trend in August 2017, it was possible to observe an average increase of $177 \%$ in the monthly issue of debentures, ceteris paribus. Assessing sector by sector, four business sectors had an average increase in their debenture issue greater than three times after the structural break: electricity, transport and logistics, retail trade, and health insurance and pharmaceutical manufacturing. The other sectors evaluated had statistically relevant increments between $174 \%$ and $231 \%$ on average, ceteris paribus.

Table 2. Test of the effect of structural break on the monthly volume of debenture issue by sector.

\begin{tabular}{|c|c|c|c|c|c|c|}
\hline Sector & $\begin{array}{l}\text { Estimated date } \\
\text { (month/year) }\end{array}$ & No of observations & F-test & $\beta_{0 i}$ & $\beta_{1 i}$ & $\beta_{2 i}$ \\
\hline \multicolumn{7}{|c|}{$\ln \left(y_{i t}\right)=\beta_{0 i}+\beta_{1 i} \cdot \ln \left(y_{t-1 i}\right)+\beta_{2 i} \cdot Q_{t i}+\varepsilon_{i t}$} \\
\hline \multirow{2}{*}{ Financial } & \multirow{2}{*}{ February 2015} & \multirow{2}{*}{108} & \multirow{2}{*}{$3.17^{*}$} & $1.829^{* * *}$ & - & $-1.022^{*}$ \\
\hline & & & & $(0.425)$ & - & $(0.574)$ \\
\hline \multirow{2}{*}{ Electricity } & \multirow{2}{*}{ September 2017} & \multirow{2}{*}{108} & \multirow{2}{*}{$16.39^{* * *}$} & $3.089^{* * *}$ & 0.081 & $3.142^{* * *}$ \\
\hline & & & & $(0.455)$ & $(0.098798)$ & $(0.686)$ \\
\hline \multirow{2}{*}{$\begin{array}{l}\text { Transport and } \\
\text { Logistics }\end{array}$} & \multirow{2}{*}{ June 2017} & \multirow{2}{*}{108} & \multirow{2}{*}{$11.67^{* * *}$} & $2.186^{* * *}$ & -0.004 & $3.014^{* * *}$ \\
\hline & & & & $(0.398)$ & $(0.097)$ & $(0.683)$ \\
\hline \multirow{2}{*}{ Retail trade } & \multirow{2}{*}{ April 2017} & \multirow{2}{*}{108} & \multirow{2}{*}{$60.19^{* * *}$} & $1.075^{* * *}$ & - & $3.933^{* * *}$ \\
\hline & & & & $(0.280)$ & - & $(0.507)$ \\
\hline \multirow{2}{*}{ IT and Telecom } & \multirow{2}{*}{ February 2017} & \multirow{2}{*}{108} & \multirow{2}{*}{$26.53^{* * *}$} & 0.410 & - & $2.309^{* * *}$ \\
\hline & & & & $(0.255)$ & - & $(0.448)$ \\
\hline \multirow{2}{*}{$\begin{array}{l}\text { Health Ins./Pharm. } \\
\text { Man. }\end{array}$} & \multirow{2}{*}{ August 2017} & \multirow{2}{*}{108} & \multirow{2}{*}{$24.30^{* * *}$} & $0.477^{*}$ & -0.011 & $3.240^{* * *}$ \\
\hline & & & & $(0.243)$ & $(0.098)$ & $(0.556)$ \\
\hline \multirow{2}{*}{ Sanitation } & \multirow{2}{*}{ July 2017} & \multirow{2}{*}{108} & \multirow{2}{*}{$15.14^{* * *}$} & $0.927^{* * *}$ & - & $1.957^{* * *}$ \\
\hline & & & & $(0.265)$ & - & $(0.503)$ \\
\hline \multirow{2}{*}{ Steelmaking } & \multirow{2}{*}{ August 2018} & \multirow{2}{*}{108} & \multirow{2}{*}{$11.93^{* * *}$} & $0.416^{* *}$ & - & $1.741^{* * *}$ \\
\hline & & & & $(0.200)$ & - & $(0.504)$ \\
\hline \multirow{2}{*}{ Total market } & \multirow{2}{*}{ August 2017} & \multirow{2}{*}{108} & $1907 * * *$ & $4.821^{* * *}$ & $0.276^{* * *}$ & $1.768^{* * *}$ \\
\hline & & & $19.0 / 79$ & $(0.678)$ & $(0.096)$ & $(0.522)$ \\
\hline
\end{tabular}

Note. Robust standard error in parentheses; ${ }^{*} \mathrm{p}$-value $<0.10{ }^{* *} \mathrm{p}$-value $<0.05 ;{ }^{* * *} \mathrm{p}$-value $<0.01$.

The dynamic panel test in Table 3 was used to assess two parameters: (a) the sectorial effect on the percentage change in the volume of debentures issued after the structural break, represented by the parameter $\delta_{i}$; (b) the fixed sectorial effect on the percentage change in the total volume of debentures issued by the sectors evaluated, represented by the parameter $\gamma_{i}$. These two parameters were analyzed in relation to the steelmaking sector, which was not included in the regression. In addition, the temporal effect on the percentage change in the monthly volume of debentures $\left(\beta_{1 i}\right)$ was also included in this assessment. The Hausman test indicated the need to work with fixed effects because of endogeneity. The Sargan test demonstrates that the instruments are exogenous with a 5\% significance ( $\mathrm{p}$-value $=0.561$ ), while the serial correlation tests demonstrate the existence of serial correlation of order $1(A R 1-p$-value $=$ $0.014)$ and no correlation serial of order 2 (AR2 - p-value $=0.477)$, as expected. 
White test was performed and error heteroscedasticity was detected, so robust standard errors were used in the models. The normality of the errors was rejected based on the Jarque-Bera test, but the sample is considered large enough for the results to be robust for this lack of normality, since the regression model has 108 observations for two explanatory variables - according to Heij, Boer, Franses, Kloek and Dijk (2004), the model must have at least ten observations for each explanatory variable.

In relation to $\delta$, the test suggests that only the electricity sector presented a statistically significant result.
After the structural break in this line of business, the total volume of debentures showed an increase of $63.70 \%$, on average (compared to the reference sector in the period prior to the break), ceteris paribus.

Regarding the sectorial fixed effect, only the financial sector did not present a statistically significant result with a 95\% confidence level. Finally, it was possible to observe a statistically significant result for the temporal effect in the percentage change in the volume of debentures issued. In this case, there was an influence equal to $12.76 \%$ increase in the total monthly volume on average, ceteris paribus.

Table 3. Panel test of the sectorial effect on the volume of monthly issue of debentures after the structural break and fixed sectoral effects.

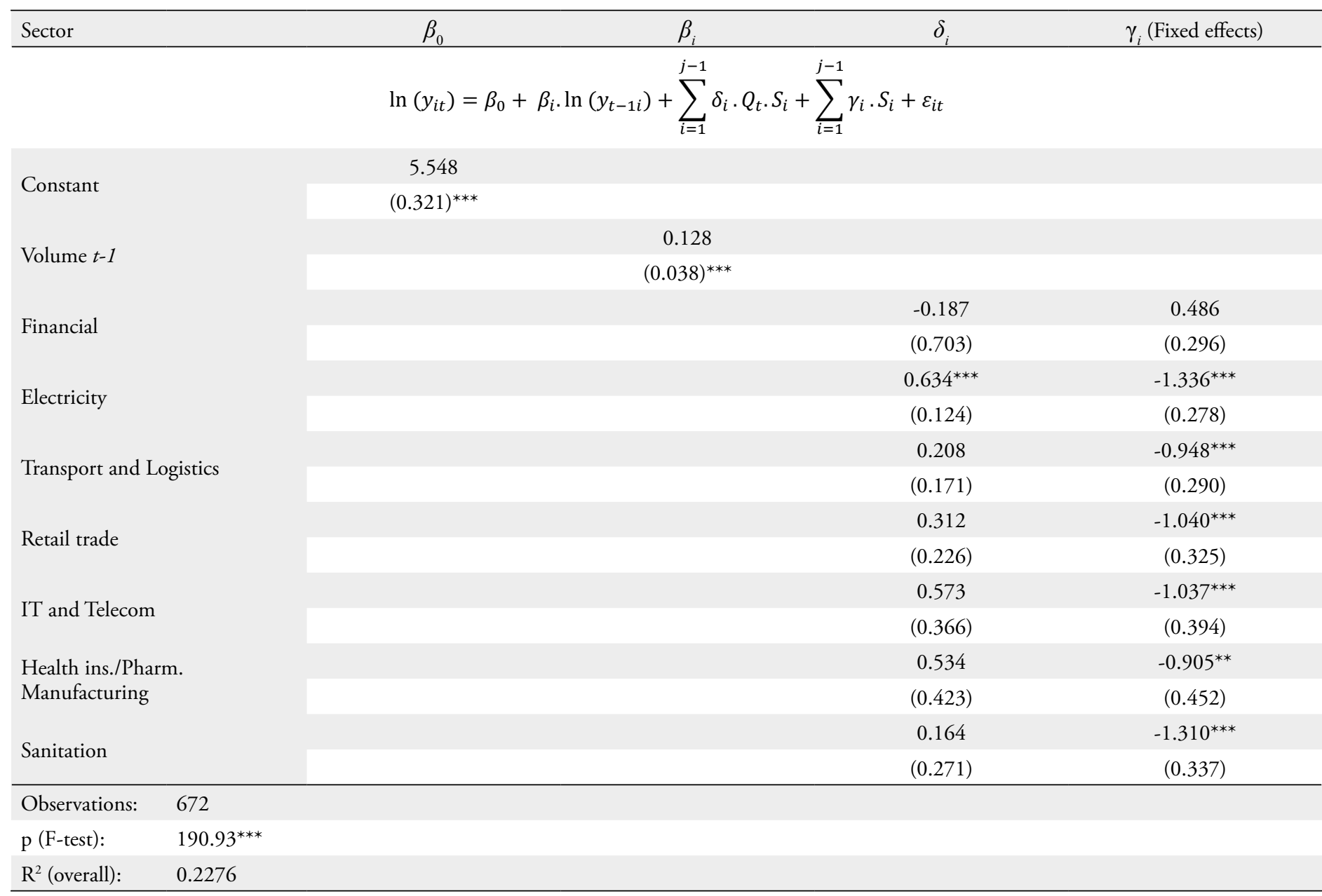

Note. Robust standard error in parentheses; ${ }^{*} \mathrm{p}$-value $<0.10 ;{ }^{* *} \mathrm{p}$-value $<0.05 ;{ }^{* * *} \mathrm{p}$-value $<0.01$.

\section{QUALITATIVE RESULTS}

The content analysis process allowed grouping the findings according to blocks of themes representing relevant factors for the phenomenon under analysis. As shown above, long-term financing in the national context is governed by several aspects, ranging from problems related to the structure of the Brazilian financial system (Castro, Kalatzis e Martins-Filho, 2015; Beck \& Levine, 2002) to the macroeconomic context experienced by the country at the time analyzed (Paula \& Faria, 2012). 
Therefore, the following blocks of factors emerging from the interviews were defined and that may explain the evolution of the debenture market and its sectorial variations: (a) reduction in state participation; (b) increased demand for debentures; (c) structure of the financial system; (d) lower interest rates in Brazil; (e) negative impact of regulatory issues; (f) negative impact of bureaucracy. Table 4 lists these factors, their mechanisms involved, and includes illustrations of quotes from the interviews conducted herein.

Table 4. Qualitative results.

\begin{tabular}{cc}
\hline Possible factors & Mechanism involved \\
\hline Decrease in state participation & $\begin{array}{c}\text { Loss of competitiveness of public } \\
\text { sources (notably BNDES) due to } \\
\text { higher relative financial costs and } \\
\text { need for guarantees }\end{array}$ \\
$\begin{array}{c}\text { Increase in the demand for de- } \\
\text { bentures }\end{array}$ & $\begin{array}{c}\text { An excess of liquidity in the hands } \\
\text { of investors has increased the } \\
\text { demand for corporate bonds as an } \\
\text { alternative capital allocation }\end{array}$ \\
\end{tabular}

Structure of the financial market

Bank credit limitations for longterm operations

Change of government and loss of competitiveness of TJLP (longterm interest rate) in relation to Selic (Brazilian federal funds rate)

Negative impact of regulatory issues

Regulation reduces the attractiveness of transactions encouraged by issuers

The bureaucratic processes to register operations in the capital market end up delaying the issue of these securities, which can increase the risk of these transactions
Illustrative quotes from the interviews

"There was a greater migration from these longer-term opera-tions to the capital market... Previously there was a lot of BNDES participation in these debt operations... In my view, this was reduced as BNDES rates increased close to market rates, thus reducing the subsidies that the bank used to pass on. At that time, the capital market began to gain more relevance due to the terms of these operations..." (Interviewee from the steelmaking sector).

"I understand that the liquidity excess in the hands of investors increased the demand for corporate bonds, which impacted the volume of transactions in the market." (Interviewee from steelmaking sector).

"In relation to debentures, the company normally focuses its efforts on ICVM 476 transactions... Debentures are still the most attractive sources at this moment... A first reason is the IOF problem. As capital market transactions do not have this tax, so, they end up being more competitive in comparison with banking operations." (Interviewee 2, from the retail trade sec-tor).

"There was a change after the impeachment of President Dilma, when companies began to resort to the national capital market more often. The main reason for this is the drop in the interest rates, which made BNDES operations relatively expensive." (Interviewee 1, from the electricity sector).

"For incentivized bond issue, companies tend to have a certain fear due to the uncertainties related to the Income Tax, especial-ly for securities that use some types of receivables as backing, such as CRA and CRI... It is not clear whether the benefit is from the securitization company or the issuer of the debenture, which increases the risk of assessment by revenue." (Interviewee 3, from the retail trade sector).

"The main point of improvement is associated with judicial bureaucratic intricacies, such as registration in notary offices. CVM is already very active in this debenture market and has already created interesting regulations that reduce debenture issue processes. However, notary offices would be the major bottlenecks of these operations." (Interviewee 4, from the electricity sector).

\section{Decrease in state participation}

According to those interviewed, with the creation of the TLP, which sought to progressively align the bank's rates with those practiced by the market, BNDES' costs, which were previously subsidized, lost competitiveness in comparison with the market. In addition, BNDES's loans require collaterals, which further reduces the appetite of these companies.

In this sense, as capital market and banking operations became more competitive compared to BNDES loans, associated with a drop in market interest rates, the preference of these companies began to change. This fact can be supported by data presented in the Ministry of Economy (Ministério da Economia, 2021), where it is possible to observe a drop in the remuneration required by the market for infrastructure corporate bonds, leaving $\mathrm{IPCA}+7.60 \%$ p.a. in 2015 to IPCA $+4.70 \%$ p.a. in 2019. In addition, the average term of these operations also increased, reaching 13.3 years in 2019 . 


\section{Increase in the demand for debentures}

Nine of the ten participants mentioned the increase in demand for debentures as one of the main reasons for the increase in the issue of debentures from 2017 onward. According to respondents, in the last three years, liquidity in the market has grown dramatically, which has increased demand by corporate bonds. In addition, most participants said that the expansion of investment platforms for individuals may have driven this increase in demand for debentures.

In line with what was exposed by those interviewed, in fact the volume raised by investment funds has soared in recent years. According to Anbima data compiled by the Ministry of Economy (Ministério da Economia, 2021), the number of infrastructure fund shareholders grew 550\% between February 2018 and December 2019, from 27,618 to 179,228 . In addition, the equity of these funds increased by $344 \%$ in the same period, reaching $\mathrm{R} \$ 16.9$ billion at the end of 2019.

In addition, even though the low liquidity of the secondary market has been a topic explored by some of the interviewees, data from Anbima show that the volume of debentures traded grew by $174 \%$ between 2017 and 2019 .

\section{Structure of the financial market}

Regarding the structure of the Brazilian financial system, there was no clear indication of what would be the best source of financing for the companies evaluated. According to the professionals approached, most of the time, they assessed funding opportunities on a case-by-case basis. This fact is supported by what was exposed by Beck and Levine (2002), who suggested that the sources of financing would have no effect on the development of companies.

In addition, these professionals mentioned the preference to allocate direct bank credit to short-term operations, thus avoiding possible liquidity problems, corroborating the view of Maksimovic and Demirgüc-Kunt (2002) that banking operations would be more associated with shorter terms.

\section{Drop in the Brazilian interest rates}

The loss of attractiveness for BNDES operations is closely associated with the relationship between the Brazilian federal funds rate (Selic) and the long-term interest rate (taxa de juros de longo prazo - TJLP), according to those interviewed. As a large part of BNDES operations used the TJLP as their base rate, these credit lines lost space in these companies' balance sheets, as exemplified below and in Figure 2.

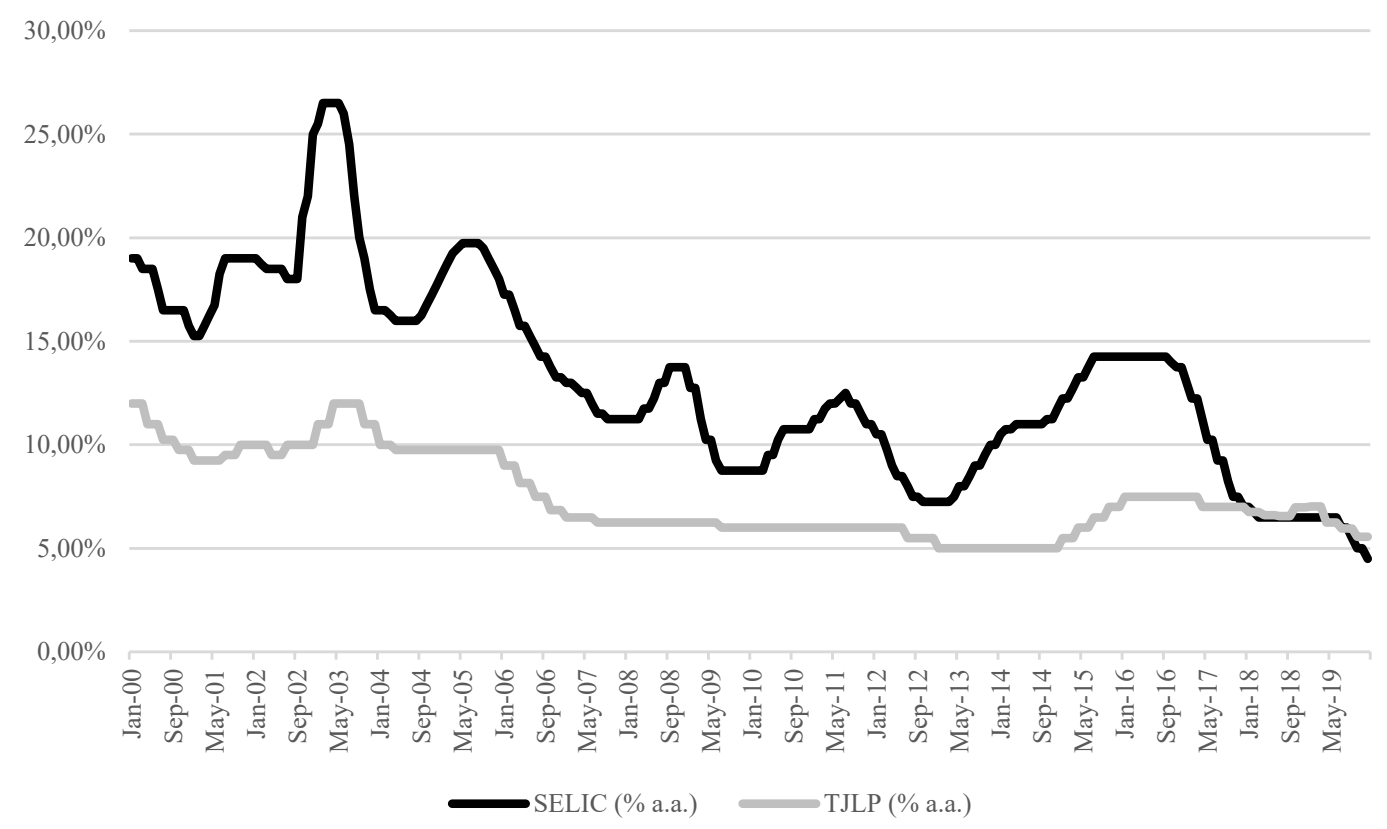

Figure 2. Comparative evolution between Selic and TJLP.

Source: Elaborated by the authors based on data from Bloomberg (https://www.bloomberg.com/ retrieved on June 10, 2020). 
Therefore, even though BNDES made available specific debt structures for projects in some sectors, which could be seen in Lazzarini et al. (2015), these instruments have become less cost-competitive.

\section{Negative impact of regulatory issues}

Interviewees addressed some regulatory changes that could boost the debenture market. First, participants reported a certain difficulty in the process of classifying their debenture operations as infrastructure projects. In addition, without mentioning specific concerns, respondents mentioned that it would be important to create regulations that would increase the liquidity of the secondary debenture market, in line with what was explored by Musacchio (2009).

Finally, specifically for incentivized operations, some professionals showed a certain insecurity in relation to the taxation of these operations, which, according to them, could be changed through clearer rules on this aspect.

\section{Negative impact of bureaucracy}

According to the interviewees, one of the factors that slow down the debenture market is bureaucracy. Bureaucratic transaction registration processes end up delaying the issue of these bonds, which can increase the risk of these transactions.

An example would be issuing under the ICVM 400 regulation. As this type of transaction targets individual investors, the issuance process can take more than three months, which often incurs in the need for solid guarantees from the banks that structure the transactions, thus impacting their costs.

However, for companies that are frequent issuers, bureaucracy does not seem to be a problem. An argument presented by the interviewees is that these companies already have specialized departments in these operations, which makes this process much easier. For these professionals, bureaucracy would have a greater impact on smaller companies.

\section{DISCUSSION}

The quantitative results of this study suggest that, in fact, there was a change in the trend in debenture issue from 2017 on, according to statistical tests of structural break. By stratifying this analysis to the main debenture-issuing sectors, it was also possible to verify statistically significant trend changes over 2017 and 2018.
Another important point of this analysis was to assess whether the behavior of the changes suffered by each business sector was similar. In this sense, the results suggest that some sectors had a more relevant performance than others, as is the case of the electricity industry, being the only one with statistically significant effects on the performance of the market as a whole after August 2017.

In general, the qualitative analysis suggests that the main factor of change in the behavior of the debenture market would be associated with the rapid fall in interest rates seen from 2017 onward. According to most respondents, this phenomenon had an impact on the demand for bonds, as well as reduced the discrepancy between the cost of subsidized BNDES instruments and the rates practiced by the market as a whole.

Furthermore, the results of the qualitative analysis suggest that, in fact, state participation, mainly through BNDES, was an important factor in the financing for the companies assessed. However, the capital market has become an important player in supporting the projects of these companies, replacing, at some level, public entities. According to the interviewees, this change would be supported mainly by the cost of these financing operations. As BNDES became less competitive in relation to private lines of credit, these companies started to resort to the market in search of more competitive financing deals.

Therefore, there were two major factors that might have changed this aspect of the market: the drop in interest rates in Brazil and the growth of the secondary debenture market. According to those interviewed, with the fall of the Selic, investors had to reallocate their investments to higher risk operations to seek greater profitability. In this sense, the demand for corporate bonds has soared, as these instruments tend to remunerate investors better, given their higher level of risk.

\section{FINAL CONSIDERATIONS}

A first aspect addressed about long-term financing is the difficulty of financing long-term projects. Authors such as Bruck (1998), Amsden (1992) and Gerschenkron (1962) have addressed the importance of the state as an essential source of support for long-term projects. This aspect was reinforced in this study, through the interviewees reports, suggesting that the state may have been an important source of funding in recent years.

Second, this study contributes to other papers on what would be the best structure of the financial system to foster economic growth, such as those of Khurana, Martin e Pereira (2006), Castro et al. (2015), Love (2003) and Beck and Levine (2002). It was evident from the interviews that, 
regardless of the financing source, the companies assessed are more concerned with problems related to the costs and terms of their financing.

In addition, even though the companies approached had access to different sources of financing, many of them chose to use subsidized lines from BNDES, which was also explored by Lazzarini et al. (2015). This finding supports the concept of misallocation of public resources aimed at financing projects and crowding out of private capital sources explored by the author and by Musacchio et al. (2017). Also, as exemplified by one of the interviewees, the country currently has thirteen thousand medium-sized companies without any type of long-term financing. Therefore, state support can have a positive effect on the development of these capital-constrained companies (Lazzarini et al., 2015; Machado, Grimaldi, Albuquerque, \& Santos, 2014; Machado et al., 2017; Musacchio et al., 2017).

Access to the capital market by small and medium-sized enterprises was debated by some of those interviewed, mainly in relation to bureaucratic and regulatory intricacies that would impact these entities. In line with what was explored by Musacchio (2009) and Triner (2000), who addressed the importance of a structured regulatory environment for the development of the capital market, respondents stated that regulatory and bureaucratic improvements would be more effective for smaller companies. As operations in the capital market need extensive documentation, according to the interviewees, smaller companies would have difficulty in complying with these requirements, as they do not have a developed internal structure, as is the case with large companies.

However, although the change seen in the debenture market in recent years appears to be sustainable according to respondents, external shocks could change this perspective. Events that have a severe impact on the economy, such as the COVID-19 pandemic, may substantially wane the attractiveness of the capital market, thus reducing the accuracy of the results of this study. In this sense, the evolution seen in this market may not be sustained in the short term, suffering deterioration already in 2020. An example of this is the Anbima data released in April this year, which show impacts on both the supply and demand for corporate bonds. According to Anbima's report, by April 2020, R \$ 7.1 billion in debentures had been issued. At this pace, the total volume for 2020 is expected to be $36 \%$ below 2019. In addition, the number of investors in infrastructure investment funds suffered a relevant contraction in 2020, falling by more than $30 \%$ in this period.

Another point also associated with the COVID-19 crisis is the increase in state participation in the economy. In moments like this, the state ends up serving as a base to maintain the financial health of strategic companies for the national economy. An example of this is the BNDES measure to pay $20 \%$ to $25 \%$ of emergency loans to help electricity distributors. What seems to be different in this measure is the fact that banks seek the support of private institutions, thus reducing the impact on its balance sheet. This government support would be based on the idea that state support would reduce distrust among private creditors, which tends to be more intense in times of credit shortage (Bruck, 1998; Gerschenkron, 1962). Therefore, the reduction of state participation through BNDES, which may have been one of the main growth vectors in the capital market, should increase again at first.

Finally, problems associated with the cost of bond issue in the capital market will have to undergo substantial changes at first. With the increase in country risk, debenture issue should also become more expensive. Thus, the competitiveness of these bonds compared to state entities operations should fall, which could reduce the companies' intention to issue debentures in these times.

That said, a first suggestion for future research on this topic would be to address the level of investment by firms in the sectors evaluated after the crisis experienced by the country at that time. It would be interesting to observe whether these companies maintained, at least in part, their level of investment in projects, as, by all indications, they should receive support from the state. Another possible approach to the evolution of the debenture market would be to explore the demand side for these bonds. Therefore, a qualitative study on the perspective of investors regarding the evolution of this market from 2017 onward could broaden the concept of this phenomenon. 


\section{REFERENCES}

Abraham, F., Cortina, J. J., \& Schmukler, S. L. (2021). The rise of domestic capital markets for corporate financing: Lessons from East Asia. Journal of Banking and Finance, 122, 105987. https://doi.org/10.1016/j.jbankfin.2020.105987

Aghion, B. A. De (1999). Development banking. Journal of Development Economics, 58(1), 83-100. https://doi.org/10.1016/S0304-3878(98)00104-7

Alles, L. (2001). Asset securitization and structured financing: future prospects and challenges for emerging market countries. IMF Waking Paper, WP/02/6(October), 555-582.

Amsden, A. H. (1992). Asia's Next Giant: South Korea and Late Industrialization. USA: Oxford University Press. https://doi.org/10.1093/0195076036.001.0001

Andrews,D.W.K.(1993).Testsforparameterinstabilityandstructural change with unknown change point. Econometrica, 61(4), 821-856. http://www.jstor.org/stable/2951764

Armijo, L. E., \& Rhodes, S. D. (2017). Explaining infrastructure underperformance in Brazil: Cash, political institutions, corruption, and policy Gestalts. Policy Studies, 38(3), 231247. https://doi.org/10.1080/01442872.2017.1290227

Barboza, R. D. M., Furtado, M., \& Humberto, G. (2018). A atuação histórica do BNDES: O que os dados têm a nos dizer? Brazilian Journal of Political Economy, 39(3), 544560. https://doi.org/10.1590/0101-35172019-2910

Beck, T., \& Levine, R. (2002). Industry growth and capital allocation: Does having a market- or bank-based system matter? Journal of Financial Economics, 64(2), 147-180. https://doi.org/10.1016/S0304-405X(02)00074-0

Bragança, G., Pessoa, M., \& Souza, G. (2015). Evolução recente do mercado de debêntures no brasil: as debêntures incentivadas. Rio de Janeiro: IPEA, Texto para discussão 2158. https:// www.ipea.gov.br/portal/images/stories/PDFs/TDs/ td 2158.pdf

Bruck, N. (1998). The role of development banks in the twentyfirst century. Journal of Emerging Markets, 3(3), 39-67. Retrieved from https://www.adfiap.org/wp-content/ uploads/2009/10/the-role-of-development-banks-in-thetwenty-first-century.pdf

Cabral, S., \& Krane, D. (2018). Civic festivals and collaborative governance. International Review of Administrative Sciences, 84(1), 185-205. https://doi.org/10.1177/0020852315615196

Campbell, D. T., \& Fiske, D. W. (1959). Convergent and discriminant validation by the multitrait-multimethod matrix. Psychological Bulletin, 56(2), 81-105. https://doi.org/10.1037/h0046016

Castro, F., Kalatzis, A. E. G., \& Martins-Filho, C. (2015). Financing in an emerging economy: Does financial development or financial structure matter? Emerging Markets Review, 23, 96-123. https://doi.org/10.1016/j.ememar.2015.04.012
Clarke, A. P. N., \& Yaros, P. S. (1988). Research blenders: commentary and response: commentary: transitions to new methodologies in nursing sciences. Nursing Science Quarterly, 1(4), 147-149. https://doi.org/10.1177/089431848800100406

Dinç, I. S. (2005). Politicians and banks: Political influences on government-owned banks in emerging markets. Journal of Financial Economics, 77(2), 453-479. https://doi.org/10.1016/j.jfineco.2004.06.011

Ehlers, T. (2014). Understanding the challenges for infrastructure finance. BIS Working Papers, (454). Retrieved from https://www.bis.org/publ/work454.pdf

Elo, S., \& Kyngäs, H. (2008). The qualitative content analysis process. Journal of Advanced Nursing, 62(1), 107-115. https://doi.org/10.1111/j.1365-2648.2007.04569.x

Ferraz,J.C., \&Coutinho,L.(2019).Investmentpolicies, development finance and economic transformation: Lessons from BNDES. Structural Change and Economic Dynamics, 48, 86-102. https://doi.org/10.1016/j.strueco.2017.11.008

Ferreira, N., Menezes, R., \& Oliveira, M. M. (2013). Structural Breaks and Cointegration Analysis in the EU Developed Markets. International Journal of Finance, Insurance and Risk Management, 3(4), 652-661. https://doi.org/10.35808/ijfirm/86

Gerschenkron, A. (1962). Economic backwardness in historical perspective. Cambridge, MA: Harvard University Press. Retrieved from https:/www.hup.harvard.edu/catalog. php?isbn=9780674226005

Hansen, B. E. (2001). The new econometrics of structural change: Dating breaks in U.S. labour productivity. Journal of Economic Perspectives, 15(4), 117-128. https://doi.org/10.1257/jep.15.4.117

Heij, C., Boer, P., Franses, P. H., Kloek, T., \& Dijk, H. K. Van (2004). Econometric methods with applications in business and economics. New York: Oxford University Press.

Hsieh, H. F., \&Shannon, S. E. (2005). Three approaches to qualitative content analysis. Qualitative Health Research, 15(9), 12771288. https://doi.org/10.1177/1049732305276687

Jick, T. D. (1979). Mixing qualitative and quantitative methods: Triangulation in action. Administrative Science Quarterly, 24(4), 602-611. Retrieved from http://www.jstor.org/stable/2392366

Jouini, J., \& Boutahar, M. (2005). Evidence on structural changes in U.S. time series. Economic Modelling, 22(3), 391-422. https://doi.org/10.1016/j.econmod.2004.06.003

Khurana, I. K., Martin, X., \& Pereira, R. (2006). Financial development and the cash flow sensitivity of cash. Journal of Financial and Quantitative Analysis, 41(4), 787-807. Retrieved from https://www.jstor.org/stable/27647274

Lazzarini, S. G, Lima, T, \& Makhoul, P. (2017). Como aumentar a atraçáo de capital privado para financiar projetos de infraestrutura no Brasil. In A. C. Pastore (Org.). Infraestrutura: Eficiência e ética. São Paulo: Elsevier. 
Lazzarini, S. G., Musacchio, A., Bandeira-de-Mello, R., \& Marcon, R. (2015). What do state-owned development banks do? Evidence from BNDES, 2002-09. World Development, 66, 237-253. https://doi.org/10.1016/j.worlddev.2014.08.016

Love, I. (2003). Financial development and financing constraints: International evidence from the structural investment model. Review of Financial Studies, 16(3), 765-791. https://doi.org/10.1093/rfs/hhg013

Machado, L., Grimaldi, D. S., Albuquerque, B. E., \& Santos, L. O. (2014). Additionality of countercyclical credit: Evaluating the impact of BNDES' PSI on the investment of industrial firms. Rio de Janeiro: Banco Nacional de Desenvolvimento Econômico e Social. Retrieved from http://web.bndes.gov.br/bib/jspui/handle/1408/7758

Machado, L., Martini, R. A., \& Gama, M. M. da (2017). Does BNDES Innovation Credit Boost Firms' R\&D Expenditures? Evidence from Brazilian Panel Data. BNDES, [S.1. : s.n.], 1-17. Retrieved from http://web.bndes.gov.br/bib/jspui/handle/1408/13595

Maksimovic, V., \& Demirgüc-Kunt, A. (2002). Funding growth in bank-based and market-based financial systems: evidence fromfirm-leveldata. JournalofFinancialEconomics, 65,337363. https://doi.org/10.1016/S0304-405X(02)00145-9

Ministério da Economia. (2021). Boletim Informativo de Debêntures Incentivadas - Janeiro 2021. 86, 1-68. Retrieved from https://www.gov.br/economia/pt-br/ centrais-de-conteudo/publicacoes/boletins/boletimde-debentures-incentivadas/2021/spe-me-boletimdebentures-lei-12-431-jan-2021.pdf/view

Musacchio, A. (2009). Experiments in financial democracy: Corporate governance and financial development in Brazil, 1882 1950. Cambridge, MA: Cambridge University Press.

Musacchio, A., \& Lazzarini, S. G. (2015). Reinventando o capitalismo de Estado: O Leviatã nos negócios: Brasil e outros países. Sáo Paulo: Editora Schwarcz. Retrieved from https://www.companhiadasletras.com.br/detalhe/ trechos/75018.pdf

Musacchio, A., Lazzarini, S., Makhoul, P., \& Simmons, E. (2017). The role and impact of development banks a review of their founding, focus, and influence. November, 1-89. Retrieved from http://people.brandeis.edu/-aldom/ papers/The Role and Impact of Development Banks - 3-92017.pdf

Najberg, S. (1989). Privatização de recursos públicos: Os empréstimos do sistema BNDES ao setor privado nacional com correção monetária parcial (Dissertation). Pontifícia Universidade Católica, Rio de Janeiro, RJ, Brazil. Retrieved from http://web.bndes.gov.br/bib/jspui/handle/1408/15687

Paula, L. F. de, \& Faria, J. A. de (2012). Mercado de títulos de dívida corporativa privada no Brasil: Aspectos estruturais e evoluçáo recente. Revista de Economia Contemporanea, 16(1), 107-137. https://doi.org/10.1590/S1415-98482012000100006
Porta, R. La, Lopez-de-Silanes, F. Shleifer, A., \& Vishny, R. W. (1998). Law and finance. Journal of Political Economy, 106(6): 1113-1155. https://doi.org/10.1086/250042

Perron, P. (2006). Dealing with structural breaks. Palgrave Handbook of Econometrics, 1, 278-352. https://doi.org/10.1016/j.gf.2006.04.004

Sale, J. E. M., Lohfeld, L. H., \& Brazil, K. (2002). Revisiting the quantitative-qualitative debate: Implications for mixedmethods research. Quality and Quantity, 36(1), 43-53. https://doi.org/10.1023/A:1014301607592

Shaoul, J. (2005). A critical financial analysis of the private finance initiative: Selecting a financing method or allocating economic wealth? Critical Perspectives on Accounting, 16(4), 441-471. https://doi.org/10.1016/j.cpa.2003.06.001

Stemler, S. (2001). An overview of content analysis. Practical Assessment, Research and Evaluation, 7(17), 2000-2001. https://doi.org/10.7275/z6fm-2e34

Stokes, D., \& Bergin, R. (2006). Methodology or "methodolatry"? An evaluation of focus groups and depth interviews. Qualitative Market Research, 9(1), 26-37. https://doi.org/10.1108/13522750610640530

Torres, E. T. Filho, \& Costa, F. N. da. (2012). BNDES e o financiamento do desenvolvimento. Economia e Sociedade, 21(spe), 975-1009. https://doi.org/10.1590/s0104-06182012000400011

Triner, G. D. (2000). Banking and economic development: Brazil, 1889-1930. London, UK: Palgrave Macmillan.

Wajnberg, D. (2014). Debêntures de infraestrutura: emissóes realizadas e perspectivas. Revista do BNDES, 41, 331-378. Retrieved from https://www.bndes.gov.br/SiteBNDES/ export/sites/default/bndes_pt/Galerias/Arquivos/ conhecimento/revista/rev4108.pdf

Webb, E. J., Campbell, D. T., Schwartz, R. D., \& Sechrest, L. (1966). Unobtrusive measures: Nonreactive research in the social sciences. The Annals of the American Academy of Political and Social Science, 368(1), 229-230. https://doi.org/10.1177/000271626636800179

White, M. D., \& Marsh, E. E. (2006). Content analysis: A flexible methodology. Library Trends, 55(1), 22-45. https://doi.org/10.1353/lib.2006.0053

Zarei, A., Ariff, M., Hook, L. S., \& Nassir, A. M. (2015). Identifying multiple structural breaks in exchange rate series in a finance research. Pertanika Journal of Social Sciences and Humanities, 23, 155-166. Retrieved from https:// pureportal.coventry.ac.uk/en/publications/identifyingmultiple-structural-breaks-in-exchange-rate-series-in

Zivot, E., \& Andrews, D. W. K. (1992). Further evidence on the great crash, the oil-price shock, and the unit-root hypothesis. Journal of Business and Economic Statistics, 10(3), 251270. https://doi.org/10.1080/07350015.1992.10509904 


\section{Authorship}

\section{Lucas Boareto da Aparecida}

Instituto de Ensino e Pesquisa (INSPER)

R. Quatá, n. 300, Vila Olímpia, 04546-042, São Paulo, SP, Brazil

E-mail address: lucasba1@al.insper.edu.br

(1) https://orcid.org/0000-0001-7257-6947

\section{Sergio Giovanetti Lazzarini}

Instituto de Ensino e Pesquisa (INSPER)

R. Quatá, n. 300, Vila Olímpia, 04546-042, São Paulo, SP, Brazil

E-mail address: sergiogl1@insper.edu.br

(1) https://orcid.org/0000-0001-8191-1241

\section{Adriana Bruscato Bortoluzzo*}

Instituto de Ensino e Pesquisa (INSPER)

R. Quatá, n. 300, Vila Olímpia, 04546-042, São Paulo, SP, Brazil

E-mail address: adrianab@insper.edu.br

(1) https://orcid.org/0000-0003-2872-031X

* Corresponding Author

\section{Funding}

The authors reported that there is no financial support for the research in this article.

\section{Conflict of Interests}

The authors have stated that there is no conflict of interest.

\section{Plagiarism Check}

The RAC maintains the practice of submitting all documents approved for publication to the plagiarism check, using specific tools, e.g.: iThenticate.

\section{Copyrights}

RAC owns the copyright to this content.

\section{Peer Review Method}

This content was evaluated using the double-blind peer review process. The disclosure of the reviewers' information on the first page, as well as the Peer Review Report, is made only after concluding the evaluation process, and with the voluntary consent of the respective reviewers and authors.

\section{Authors' Contributions}

$1^{\text {st }}$ author: conceptualization (lead); data curation (lead); formal analysis (equal); funding acquisition (equal); investigation (equal); methodology (equal); project administration (equal); resources (equal); software (equal); supervision (equal); validation (equal); visualization (equal); writing-original draft (equal); writing-review \& editing (equal).

$2^{\text {nd }}$ author: conceptualization (equal); data curation (equal); formal analysis (equal); funding acquisition (equal); investigation (equal); methodology (equal); project administration (equal); resources (equal); software (equal); supervision (equal); validation (equal); visualization (equal); writing-original draft (equal); writing-review \& editing (equal).

$3^{\text {rd }}$ author: conceptualization (supporting); data curation (supporting); formal analysis (equal); funding acquisition (equal); investigation (equal); methodology (equal); project administration (equal); resources (equal); software (equal); supervision (equal); validation (equal); visualization (equal); writing-original draft (equal); writing-review \& editing (equal).

\section{Data Availability}

The authors claim that one of the databases used does not allow the disclosure of data, but that the other data were disclosed by them. Furthermore, the authors claim that the codes used in the research were shared. The data and codes shared by the authors were made publicly available through the Harvard Dataverse platform and can be accessed at:

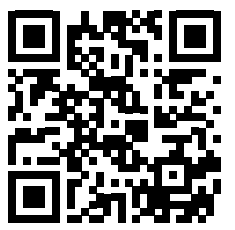

Aparecida, Lucas Boareto da; Lazzarini, Sergio Giovanetti; Bortoluzzo, Adriana Bruscato, 2021, "Replication Data for: Long term financing: exploring the recent development on the Brazilian bond market - published by RACRevista de Administração Contemporânea", Harvard Dataverse, V1. https://doi.org/10.7910/DVN/ZWNO6O

RAC encourages data sharing but, in compliance with ethical principles, it does not demand the disclosure of any means of identifying research subjects, preserving the privacy of research subjects. The practice of open data is to enable the reproducibility of results, and to ensure the unrestricted transparency of the results of the published research, without requiring the identity of research subjects. 


\section{APPENDIX A.}

\section{Descriptive analysis}

The descriptive analysis of the volume of debentures issued in the domestic market suggests that the electricity sector stood out in relation to the number of operations carried out in the years herein evaluated, with 265 operations (Table A1). In the period analyzed, $16.70 \%$ of the debentures issued came from companies in this line of business. In addition, excluding the financial sector from the analysis, $18.70 \%$ of the financial resources raised via debentures went to the electricity sector. Another point demonstrated by the descriptive analysis is that the average volume per debenture operation did not vary much in the business sectors assessed. Only the financial sector presented operations with individual values well above the market average.

Table A1. Descriptive analysis of the volume of debentures issued in the sectors assessed.

\begin{tabular}{|c|c|c|c|c|}
\hline Sector & Number of issue operations & $\begin{array}{l}\text { Total volume } \\
\text { (R\$ million) }\end{array}$ & $\begin{array}{c}\overline{\boldsymbol{X}} \text { Average volume } \\
(\mathrm{R} \$ \text { million })\end{array}$ & $\begin{array}{c}\sigma-\text { Standard deviation } \\
(\mathrm{R} \$ \text { million })\end{array}$ \\
\hline Financial & 135 & 240,547 & 1,782 & 2,905 \\
\hline Electricity & 265 & 87,400 & 330 & 381 \\
\hline Transport and Logistics & 136 & 44,026 & 324 & 310 \\
\hline Retail trade & 93 & 32,236 & 347 & 311 \\
\hline IT and Telecom & 32 & 16,199 & 506 & 806 \\
\hline Health Ins./Pharm. Man. & 30 & 13,653 & 455 & 397 \\
\hline Sanitation & 56 & 11,679 & 209 & 170 \\
\hline Steelmaking & 14 & 10,682 & 763 & 641 \\
\hline Total market & 1.585 & 707,539 & 446 & 1,060 \\
\hline
\end{tabular}

Note. Source: Own elaboration. 